\title{
Cardiovascular risk and lifestyle in patients with chronic kidney disease
}

\author{
Risco cardiovascular e estilo de vida em pacientes com doença renal crônica
}

Érika de Moura Fé ${ }^{1}$, Açucena Leal de Araújo ${ }^{1}$, Tatiana Victória Carneiro Moura ${ }^{1}$, Dinah Alencar Melo Araújo ${ }^{1}$, Valdenia Maria de Sousa ${ }^{1}$, Ana Roberta Vilarouca da Silva ${ }^{1}$

Objective: to correlate cardiovascular risk factors of patients with kidney disease with elevated blood pressure levels. Methods: this is a cross-sectional study with 150 patients on hemodialysis. Two forms were used, one referring to socioeconomic factors and the other to lifestyle. Results: the sample consisted predominantly of male patients, aged over 52 years old, married and not working. Blood pressure levels were the most affected of the cardiovascular risk factors, where $78.0 \%$ had systolic blood pressure above ideal values. A statistically significant association was found between blood pressure and age $(\mathrm{p}=0.024)$ and between blood pressure and ability to deal with stress ( $\mathrm{p}=0.015)$. Conclusion: through this study, it was verified that the statistical significance between the variables indicates that high systolic blood pressure, age and ability to deal with stress favor cardiovascular risk factors in patients with chronic kidney disease.

Descriptors: Risk Factors; Life Style; Cardiovascular Diseases.

Objetivo: correlacionar fatores de risco cardiovascular de pacientes com doença renal com níveis pressóricos elevados. Métodos: estudo transversal realizado com 150 pacientes em hemodiálise. Foram utilizados dois formulários, um referente aos fatores socioeconômicos e outro ao estilo de vida. Resultados: a amostra foi composta predominantemente por pacientes do sexo masculino, idade acima de 52 anos, casados e não exercendo atividade laboral. Dos fatores de risco cardiovascular, os níveis pressóricos foram os mais alterados, onde 78,0\% estavam com pressão arterial sistólica acima dos valores ideais. Foi encontrada associação estatisticamente significativa entre pressão arterial e idade $(p=0,024)$ e entre pressão arterial e capacidade de lidar com o estresse ( $p=0,015)$. Conclusão: por meio deste estudo, pôde-se verificar que a significância estatística entre as variáveis indica que a pressão arterial sistólica elevada, a idade e a capacidade em lidar com o estresse favorecem os fatores de risco cardiovascular em pacientes com doença renal crônica.

Descritores: Fatores de Risco; Estilo de Vida; Doenças Cardiovasculares.

${ }^{1}$ Universidade Federal do Piauí. Picos, PI, Brazil. 


\section{Introduction}

The individual with chronic disease faces major challenges daily involving changes in lifestyle. Chronic kidney insufficiency causes invasive and stressful situations to the patient regarding the particularities required by the hemodialysis treatment, leading to changes that limit daily activities and favoring sedentarism and functional deficiency, factors that directly affect the quality of life and can cause other health complications.

Chronic kidney disease is characterized by a reduced glomerular filtration rate and increased albuminuria, conditions that, if associated with cardiovascular disease, imply high mortality rates in the affected population. The hemodialysis treatment can be quite long and cause great changes in the body, but it represents quality of life for thousands of patients ${ }^{(1)}$.

According to information from the Brazilian Chronic Dialysis Survey 2016, there were a total of 834 dialysis units enrolled in the Brazilian Society of Nephrology in July of that year, and 747 of these units had an active program for chronic dialysis, in which the estimated total number of patients on dialysis was 122,825 . This represents an increase of 31,500 patients in the last five years, as well as an average annual increase of $6.3 \%$ in the number of patients. It should be noted that most of these patients were diagnosed with arterial hypertension (34.0\%) and diabetes mellitus $(30.0 \%)$ as underlying diseases ${ }^{(2)}$.

Considering that hemodialysis treatment may influence lifestyle and lead to cardiovascular disorders, it is questioned: which modifiable risk factors in the lifestyle of patients with chronic kidney disease can influence the onset of cardiovascular diseases?

This hypothesis is due to the peculiarities of the disease, when many patients stop working and become sedentary and, consequently, also associate modifiable risk factors such as hyperlipidemia, smoking, alcoholism, hyperglycemia, obesity, and poor diet. However, the change in the lifestyle of this population brings benefits to adherence to hemodialysis treat- ment and reduction of the risk of cardiovascular diseases.

This study is relevant because it deals with a health problem of high incidence, which affects individuals indistinctly, and because there is limited empirical evidence in the region of accomplishment of the research. Thus, it was aimed to correlate cardiovascular risk factors of patients with kidney disease with high blood pressure levels.

\section{Methods}

This is a cross-sectional study performed in a hemodialysis clinic located in the central-south region of the State of Piauí, Brazil, from March to November 2017. The non-probabilistic sample consisted of 150 patients who attended the following inclusion criteria: be patient with chronic kidney disease undergoing hemodialysis and be treated by the selected health institution, regardless of the date of initiation of treatment.

The included patients were contacted to participate in the research, in the waiting room where they waited for the session time, where the objective of the research was individually presented. At the time, participants were explained that, if they agreed, they would respond to two forms, one on socioeconomic data and cardiovascular risk factors and the other containing questions on lifestyle, and checking anthropometric data.

The application of the forms was done individually in a reserved room in the health institution by the researcher and the team trained by her, composed of four people. The questions were read by the interviewer so there was no misinterpretation by the interviewee, which lasted approximately ten minutes.

The variables were grouped in socioeconomic, lifestyle and cardiovascular risk factors. They were collected in two forms, one containing questions related to gender, age, origin and family group, and another related to lifestyle. There was also anthropometric data collection: weight, height, and waist circumference, besides to blood pressure measurement. 
The weight reflects the sum of all body components. In hemodialysis patients, weight measurement should be performed before and after the dialysis session. For this research, the "dry weight" of the patient, which refers to body weight without detectable peripheral edema, was considered ${ }^{(3)}$.

As for the height, it is known that in healthy adults, the reduction of height occurs with advancing age. In individuals with chronic kidney disease, the presence of bone disorders may lead to reduced stature. For patients who wander, the stature was measured with the individual standing from the anthropometric tape attached to the wall of the hemodialysis room, with a scale between $1.0 \mathrm{~m}$ and $2.0 \mathrm{~m}$. However, since it was impossible to use the conventional method and if the patient did not know how to accurately inform their height, the height was estimated from the "Chumlea equation", developed for the elderly people, using the knee height measurement because it does not change with age $\mathrm{e}^{(3)}$.

The Body Mass Index (BMI) is the most commonly used among the anthropometric indicators to evaluate the nutritional status of individuals and populations, and it is considered of universal use. From the measurements of weight and height, the Body Mass Index was calculated by the weight to height ratio. For the general population, the range of normal body mass index is between 18.5 and $24.9 \mathrm{~kg} / \mathrm{m}^{2}$, being overweight (BMI 25 to $29.9 \mathrm{~kg} / \mathrm{m}^{2}$ ) and obesity (BMI $\geq 30 \mathrm{~kg} / \mathrm{m}^{2}$ ). The term excess of weight was used to refer to overweight or obese individuals (BMI $\geq 25$ $\left.\mathrm{kg} / \mathrm{m}^{2}\right)^{(4)}$.

Waist circumference is a marker of central adiposity that identifies risks associated with metabolic and cardiovascular complications. Waist circumference measurement was performed at the end of the hemodialysis session, so there were no changes due to the accumulation of fluid in the abdominal region. According to the Brazilian Society of Diabetes, the following values are defined as abdominal obesity: for men $\geq 102 \mathrm{~cm}$ and for women $\geq 88 \mathrm{~cm}^{(4-5)}$.

Blood pressure was determined following the recommendations and cut-off points described in the VII Brazilian Guidelines for Hypertension. The values of systolic blood pressure $\geq 121 \mathrm{mmHg}$ and/or diastolic blood pressure $\geq 81 \mathrm{mmHg}^{(6)}$ were adopted as a reference for increased blood pressure.

The "Fantastic Lifestyle" form, developed at the Department of Family Medicine at McMaster University, Canada in 1984 was used to evaluate the lifestyle. Although it was validated for young adults, the instrument corresponded to the objectives proposed in this study, having issues related to cardiovascular disease, such as smoking, eating, stress, physical activity, and alcoholism. The form considers the behavior of individuals in the last month, whose results allow determining the association between lifestyle and health. The instrument has 25 questions divided into nine domains, which are: Family and friends; Sleep, seatbelt, stress and safe sex; Type of behavior; Introspection; Job; Physical activity; Nutrition; Cigarette and drug; Alcohol $^{(7)}$.

The data were organized and processed using the program Statistical Package for the Social Sciences, version 20.0. For the descriptive analysis, the calculation of absolute and relative frequencies were used, besides the measures of central tendency (average and/or median) and of dispersion (standard deviation and/or interquartile range). The Kolmogorov-Smirnov test (K-S) was applied to evaluate the normal distribution of the quantitative variables in their means.

For analytical statistics, Pearson's Chi-square test $\left(\mathrm{x}^{2}\right)$ was used to verify the association of mean systolic blood pressure with age and lifestyle variables of the participants to observe discrepancies between the frequencies observed and expected from the events studied. The reference value for statistical significance used was $\mathrm{p}<0.05$. The results were presented in tables, and later there was a discussion based on the relevant literature.

The project was approved by the Research Ethics Committee of the Federal University of Piauí, under Opinion no 2,165,831 and the CAAE no 
$68705217,4,0000,8057$. Those who agreed to participate in the survey and who were over eighteen years old were asked to sign the two-letter Consent Form. For those under eighteen years old, the parents or guardians were also requested to sign. The research was conducted in accordance with the ethical standards required.

\section{Results}

A total of 150 patients undergoing hemodialysis were evaluated, most of them were male (61.3\%), with ages ranging from 17 to 85 years old, with a mean of 55.1 years old and the most frequent age group was 5268 years old (34.0\%). The predominant self-reported skin color was brown/mulatto (55.3\%). Regarding the employment situation, $94.0 \%$ answered that they did not work.

The predominant family income was a minimum wage (R\$937.00) or less (62.7\%). Regarding the marital status, $54 \%$ were married. Regarding the educational level, $48.7 \%$ had only incomplete elementary education.

Patients' treatment time was also investigated, ranging from 1 to 204 months (17 years), the highest percentage being less than one year of treatment (30.7\%), with a mean and standard deviation of 45.2 \pm 47.9 months, respectively, although $44.7 \%$ had three years or more of hemodialysis.

Regarding cardiovascular risk factors, 30.0\% were overweight, with mean and standard deviation of $24.1 \pm 16.8 \mathrm{~kg} / \mathrm{m}^{2}(\mathrm{p}<0.000)$, distributed in $22.0 \%$ and $8.0 \%$ with overweight and obesity, respectively. Regarding waist circumference, $26.0 \%$ presented abdominal obesity, with mean and standard deviation of $87 \pm 12.9 \mathrm{~cm}(\mathrm{p}<0.007)$. Regarding pressure levels, $78.0 \%$ had mean systolic blood pressure above ideal values, with a mean and standard deviation of 142.9 $\pm 26.8 \mathrm{mmHg}(\mathrm{p}<0.000)$. Regarding mean diastolic blood pressure, $29.3 \%$ presented numbers above ideal levels, with mean and standard deviation of $75.6 \pm$ 12.4mmHg $(\mathrm{p}<0.009)$ (Table 1$)$.
Table 1 - Distribution of participants' cardiovascular risk factors

\begin{tabular}{|c|c|}
\hline Variable & n (\%) \\
\hline \multicolumn{2}{|l|}{ Body mass index } \\
\hline Low weight & $27(18.0)$ \\
\hline Eutrophic & $78(52.0)$ \\
\hline Overweight & $33(22.0)$ \\
\hline Obesity & $12(8.0)$ \\
\hline \multicolumn{2}{|l|}{ Waist circumference } \\
\hline Eutrophic & $111(74.0)$ \\
\hline Abdominal obesity & $39(26.0)$ \\
\hline \multicolumn{2}{|l|}{ Mean systolic blood pressure } \\
\hline Normal & $33(22.0)$ \\
\hline Pre-hypertension & $42(28.0)$ \\
\hline Arterial hypertension & $75(50.0)$ \\
\hline \multicolumn{2}{|l|}{ Mean diastolic blood pressure } \\
\hline Normal & $106(70.7)$ \\
\hline Pre-hypertension & $23(15.3)$ \\
\hline Arterial hypertension & $21(14.0)$ \\
\hline \multicolumn{2}{|l|}{ Physical activity } \\
\hline Yes & $86(57.3)$ \\
\hline Sedentary & $64(42.7)$ \\
\hline \multicolumn{2}{|l|}{ Alcoholism } \\
\hline Yes & $9(6.0)$ \\
\hline No & $141(94.0)$ \\
\hline \multicolumn{2}{|l|}{ Smoking } \\
\hline Smokes more than 10 cigarettes/day & $2(1.3)$ \\
\hline Smokes 1 to 10 cigarettes/day & $10(6.7)$ \\
\hline None in the last six months & $1(0.7)$ \\
\hline None in the last year & $3(2.0)$ \\
\hline Never smoked & 134(89.3) \\
\hline
\end{tabular}

Due to the high mean systolic blood pressure index (78.0\%), the values of this item were crossed with age and lifestyle variables that can lead to this change: ability to deal with stress in the day by day; physical activity; daily consumption in excess of foods that contain too much salt, animal fat and snack foods; and daily intake of caffeinated beverages such as coffee, tea and Coca-Cola. Table 2 below shows the results of such associations. 
Table 2 - Association of mean systolic blood pressure with age and lifestyle variables of participants

\begin{tabular}{|c|c|c|c|c|}
\hline \multirow[b]{2}{*}{ Variable } & \multicolumn{3}{|c|}{ Mean systolic blood pressure } & \multirow[b]{2}{*}{$\mathbf{p}^{*}$} \\
\hline & $\begin{array}{c}\text { Normal } \\
\text { n(\%) }\end{array}$ & $\begin{array}{c}\text { Pre-hyper- } \\
\text { tension } \\
\text { n(\%) }\end{array}$ & $\begin{array}{c}\text { Arterial hy- } \\
\text { pertension } \\
\text { (\%) }\end{array}$ & \\
\hline Age/Age group (years old) & & & & 0.024 \\
\hline 17 to 34 & $3(2.0)$ & $10(6.7)$ & $7(4.7)$ & \\
\hline 35 to 51 & $11(7.3)$ & $15(10.0)$ & $15(10.0)$ & \\
\hline 52 to 68 & $14(9.3)$ & $9(6.0)$ & $28(18.7)$ & \\
\hline 69 to 85 & $5(3.3)$ & $8(5.3)$ & $25(16.7)$ & \\
\hline Ability to cope with stress & & & & 0.015 \\
\hline Never & $4(2.7)$ & $7(4.7)$ & $8(5.3)$ & \\
\hline Rarely & $6(4.0)$ & $4(2.7)$ & $6(4.0)$ & \\
\hline Sometimes & $12(8.0)$ & $8(5.3)$ & $36(24.0)$ & \\
\hline Often & $2(1.3)$ & $6(4.0)$ & $14(9.3)$ & \\
\hline Always & $9(6.0)$ & $17(11.3)$ & $11(7.3)$ & \\
\hline Physical activity & & & & 0.665 \\
\hline Yes & $17(11.3)$ & $26(17.3)$ & $43(28.7)$ & \\
\hline Sedentary & $16(10.7)$ & $16(10.7)$ & $32(21.3)$ & \\
\hline Food (items per day) & & & & 0.548 \\
\hline 4 & $11(7.3)$ & $11(7.3)$ & $21(14.0)$ & \\
\hline 3 & $1(0.7)$ & $2(1.3)$ & $9(6.0)$ & \\
\hline 2 & $7(4.7)$ & $7(4.7)$ & $9(6.0)$ & \\
\hline 1 & $4(2.7)$ & $9(6.0)$ & $9(6.0)$ & \\
\hline None & $10(6.7)$ & $13(8.7)$ & $27(18.0)$ & \\
\hline Caffeine (times per day) & & & & 0.076 \\
\hline$>10$ & - & - & $1(0.7)$ & \\
\hline 7 to 10 & - & $1(0.7)$ & $1(0.7)$ & \\
\hline 3 to 6 & $7(4.7)$ & $14(9.3)$ & $9(6.0)$ & \\
\hline 1 to 2 & 19(12.7) & $26(17.3)$ & $52(34.7)$ & \\
\hline Never & $7(4.7)$ & $1(0.7)$ & $12(8.0)$ & \\
\hline
\end{tabular}

The sample showed a statistically significant level for the relationship between mean systolic blood pressure and age $(\mathrm{p}=0.024)$ and ability to deal with stress daily $(\mathrm{p}=0.015)$. Patients aged $52-85$ years old (35.4\%) were found to have a mean systolic blood pressure at levels considered as hypertension. Regarding the stress, the results showed that 69 people who correspond to $46.0 \%$ of the total sample, are never rarely and are sometimes able to cope with stress daily, both with systolic blood pressure levels mean values above normal values, that is pre-hypertension or arterial hypertension.

\section{Discussion}

The transverse character and the health status of the patients were highlighted among the limitations of the study, mainly due to the difficulty of collecting anthropometric data such as weight, height, and waist circumference, due to their collection occurring at the end of the hemodialysis session and most of the patients were unstable, hindering to perform the data collection and, consequently, the results, reducing the generalization. In spite of these difficulties and limitations, the study enables precursor and relevant results in the area of nephrology, where new investigations can be carried out with a similar public and with a larger sample that encompasses a larger number of patients, confronting the findings and find out the major cardiovascular risk factors that can be minimized through lifestyle changes.

This study analyzed the cardiovascular risk factors associated with the lifestyle of 150 patients. From the application of two forms and obtaining the anthropometric measures, it was possible to collect data and qualify them regarding lifestyle and cardiovascular risk.

Patients between 17 and 85 years old, with a mean of 55.1 years old and prevalence of the age range of 52 to 68 years old and most male were part of the sample. Participants underwent hemodialysis at the health institution in the interval of 1 to 204 months, with an average of 45.2 months, and $68.7 \%$ were under treatment for less than five years. Studies performed with similar participants obtained similar results $^{(8-9)}$.

Regarding the family income, $62.7 \%$ had monthly income of a minimum wage ( $\mathrm{R} \$ 937.00)$ or less and $94.0 \%$ did not work. Regarding the labor situation, in a study involving 18 patients submitted to hemodialysis at the Hospital Clínica Renal, Hospital Santa Lucía, 83.3\% did not perform any type of work outside their home. It was verified that the incapacity for work also influences the life of the person, since it hinders the maintenance of formal employment bon- 
ds, due to the peculiarity of the disease, that is, the routine of the treatment, complications and physical limitations ${ }^{(10)}$.

Regarding the cardiovascular risk factors, the excess weight was classified according to the values found through the calculation of the patients' body mass index. With a mean of $24.1 \pm 16.8$, the prevalence of overweight patients reached a total of $28.0 \%$ of the sample, where $22.0 \%$ were overweight and $8.0 \%$ were obese. The same result was found in a study with 90 patients from a hemodialysis clinic in the city of Belo Horizonte, Brazil, to compare the nutritional status of hemodialysis with malnutrition, showing a mean body mass index of $24.1 \mathrm{~kg} / \mathrm{m}^{2}$, that is, within the eutrophic parameter ${ }^{(11)}$.

Considering the values of waist circumference above the upper limit of $102 \mathrm{~cm}$ for men and $88 \mathrm{~cm}$ for women, a percentage of $26.0 \%$ of abdominal obesity patients was obtained, and the overall mean was $87 \pm$ $12,9 \mathrm{~cm}$. It is important to note that the average waist circumference obtained is lower when compared to the current literature, being a positive indicator ${ }^{(12)}$.

The results in the pressure levels obtained percentages above the ideal parameters recommended by the VII Brazilian Hypertension Guidelines, mainly the systolic values. Based on current literature, hypertension has been considered a present condition in chronic kidney disease. A study of 1,215 patients in hemodialysis programs for chronic renal failure in the city of Porto Alegre, RS showed an arterial hypertension found in $87.5 \%$ of the patients studied, with a mean systolic blood pressure of $146.9 \mathrm{mmHg}$ and mean diastolic blood pressure of $82.5 \mathrm{mmHg}$. More than half $(59.3 \%)$ of the 386 patients evaluated in a general medical clinic of a university hospital in the city of São Paulo presented arterial hypertension. This is because, besides to being one of the most important causes for the establishment and development of the disease, arterial hypertension is a consequence of chronic kidney disease ${ }^{(6,13-14)}$.

In this sense, by crossing the variable mean systolic blood pressure with age and other variables of the lifestyle that could somehow cause elevation of this parameter, the variables related to age and the capacity to deal with daily stress in the study were statistically significant. Regarding age, the result is similar to the recommendation by the Brazilian Society of Cardiology, in which age $>55$ years old for men and $>65$ years old for women are considered as a cardiovascular risk factor. A study conducted with elderly patients with a mean age of 68.26 years old who were on conservative treatment at the uremia outpatient clinic in a public hospital showed that $77.1 \%$ had high blood pressure as a consequence of chronic kidney disease $^{(6,15)}$.

Regarding the stress, according to a study of 112 volunteers, 56 of them with hypertension in stages 1 (mild hypertension) and 2 (moderate hypertension), attended in the Hypertension and Diabetes Program of a municipal health center in Rio de Janeiro, showed that 64 (57.1\%) of the 112 participants were stressed. Regarding blood pressure (with and without hypertension), 46 (82.1\%) of 56 hypertensive patients presented stress; while only $18(32.1 \%)$ of the 56 without hypertension were stressed. In this sense, stress can lead to the onset and maintenance of hypertension and may constitute a barrier to adherence to treatment ${ }^{(16)}$.

Thus, the results found are a warning for the population with chronic kidney disease, as well as the possibilities for professionals in health institutions to develop strategies for improving the lifestyle of chronic kidney patients, especially for the diet, decrease of stressors and the search for alternatives to perform labor activity, since a good portion of the sample does not work, which can lead to sedentary or social isolation. Chronic kidney disease promotes several changes in the lives of affected individuals, which lead to physical, mental and social suffering. If associated with a cardiovascular disease, this suffering tends to increase, so the best thing to do is intervene in cardiovascular risk factors to avoid such damages, leading to an improvement in the quality of life of this population. 


\section{Conclusion}

Through this study, it was possible to verify that the statistical significance between the variables indicates that high systolic blood pressure, age and capacity to deal with stress favor the cardiovascular risk factors in patients with chronic kidney disease.

\section{Collaborations}

Fé EM contributed with the conception and design, interpretation of the data and writing of the article. Araújo AL contributed with data analysis and interpretation and article writing. Moura TVC and Araújo DAM contributed with the conception and design. Sousa VM contributed with the conception and design and writing of the article. Silva ARV contributed with the relevant critical review of the intellectual content and final approval of the version to be published.

\section{References}

1. Ito S, Yoshida M. Protein-bound uremic toxins: new culprits of cardiovascular events in chronic kidney disease patients. Toxins (Basel). 2014; 6(2):665-78. doi: http://dx.doi.org/10.3390/ toxins 6020665

2. Sesso RC, Lopes AA, Thomé FS, Lugon JR, Martins CT. Brazilian chronic dialysis survey 2016. J Bras Nefrol. 2017; 39(3):261-66. doi: http://dx.doi. org/10.5935/0101-2800.20170049

3. Calado IL. Avaliação e diagnóstico nutricional na doença renal crônica. São Luís: UFMA; 2016.

4. Associação Brasileira para o Estudo da Obesidade e da Síndrome Metabólica (ABESO). Diretrizes Brasileiras de Obesidade 2016. São Paulo: ABESO; 2016.

5. Sociedade Brasileira de Diabetes (SBD). Diretrizes da Sociedade Brasileira de Diabetes 2013 - 2014. São Paulo: AC Farmacêutica; 2014.
6. Malachias MVB, Póvoa RMS, Nogueira AR, Souza D, Costa LS, Magalhães ME, et al. $7^{\text {th }}$ Brazilian Guideline of Arterial Hypertension. Arq Bras Cardiol. 2016; 107(Suppl 3):1-83. doi: http:// dx.doi.org/10.5935/abc.20160152

7. Rodrigues-Añez CR, Reis RS, Petroski EL. Brazilian Version of a Lifestyle Questionnaire: Translation and Validation for Young Adults. Arq Bras Cardiol. 2008; 91(2):102-9. doi: http://dx.doi. org/10.1590/S0066-782X2008001400006

8. Bettoni LC, Ottaviani AC, Orlandi FS. Relationship between self-care and depression and anxiety symptoms in individuals undergoing hemodialysis. Rev Rene. 2017; 18(2):181-86. doi: http://dx.doi. org/10.15253/2175-6783.2017000200006

9. Marinho CLA, Oliveira JF, Borges JES, Silva RS, Fernandes FECV. Quality of life of chronic renal patients undergoing hemodialysis. Rev Rene. 2017; 18(3):396-403. doi: http://dx.doi. org/10.15253/2175-6783.2017000300016

10. Marchesan M, Krug RR, Barbosa AR, Rombaldi AJ. Percepção de pacientes em hemodiálise sobre os benefícios e as modificações no comportamento sedentário após a participação em um programa de exercícios físicos. Rev Bras Ciênc Esporte. 2017; 39(3):314-21. doi: http://dx.doi.org/10.1016/j. rbce.2016.01.012

11. Ribeiro M, Araújo ML, Cunha L, Ribeiro D, Pena G. Análise de diferentes métodos de avaliação do estado nutricional de pacientes em hemodiálise. Rev Cuid. 2015; 6(1):932-40. doi: http://dx.doi. org/10.15649/cuidarte.v6i1.163

12. Fassbinder TRC, Winkelmann ER, Schneider J, Wendland J, Oliveira OB. Functional capacity and quality of life in patients with chronic kidney disease in pre-dialytic treatment and on hemodialysis - a cross sectional study. J Bras Nefrol. 2015; 37(1):47-54. doi: http://dx.doi. org/10.5935/0101-2800.20150008

13. Burmeister JE, Mosmann CB, Costa VB, Saraiva RT, Grandi RR, Bastos JP, et al. Prevalence of Cardiovascular Risk Factors in Hemodialysis Patients - The Cordial Study. Arq Bras Cardiol. 2014; 102(5):473-80. doi: http://dx.doi.org/10.5935/ abc. 20140048 
14. Pinho NA, Oliveira RCB, Pierin AMG. Hypertensive patients with and without kidney disease: assessment of risk factors. Rev Esc Enferm USP. 2015; 49(n.esp):101-8. doi: http://dx.doi. org/10.1590/S0080-623420150000700015

15. Pereira RMP, Batista MA, Meira AS, Oliveira MP, Kusumota L. Quality of life of elderly people with chronic kidney disease in conservative treatment. Rev Bras Enferm. 2017; 70(4):851-9. doi: http:// dx.doi.org/10.1590/0034-7167-2017-0103
16. Moxotó GFA, Malagris LN. Raiva, stress emocional e hipertensão: um estudo comparativo. Psicol Teor Pesq. 2015; 31(2):221-7. doi: http://dx.doi. org/10.1590/0102-37722015021189221227 